J. Amer. Soc. Hort. Sci. 116(5):770-773. 1991.

\title{
Honey-bee-mediated Cross- versus Self-pollination of 'Sharpblue' Blueberry Increases Fruit Size and Hastens Ripening
}

\author{
Gregory A. Lang \\ Department of Horticulture, Louisiana Agricultural Experiment Station, Louisiana State University, \\ Baton Rouge, LA 70803 \\ Robert G. Danka \\ U.S. Department of Agriculture; Agricultural Research Service; Honey Bee Breeding, Genetics, and \\ Physiology Laboratory; Baton Rouge, LA 70820 \\ Additional index words. southern highbush blueberry, Vaccinium corymbosum hybrids, fruit ripening, seed number, \\ honey bee, Apis mellifera \\ Abstract. To study self- and cross-pollination effects on fruit development in southern highbush (mainly Vaccinium \\ corymbosum L.) blueberries, 'Sharpblue' plants were caged with honey bees (Apis mellifera L.) and other 'Sharpblue' \\ or 'Gulfcoast' plants at anthesis. Ratios of pollinizer : fruiting flowers ranged from 2.1 to 4.5. Cross-pollination \\ increased fruit size by $\approx 14 \%$ and seed count by $27 \%$ but did not influence fruit set. Overall, seed count decreased \\ by $\mathbf{5 8 \%}$ during the 30 days of harvest, but this did not directly affect fruit size. Seed count appeared to influence \\ earliness of ripening as much as it influenced fruit size. Cross-pollination increased the harvest percentage of early- \\ ripening fruits by $140 \%$ and of premium market fruits (those $\geq \mathbf{0 . 7 5} \mathrm{g}$ ) by $13 \%$ and decreased the percentage of small \\ fruits by $66 \%$. Consequently, a $43 \%$ increase in premium early market crop value (nearly $\$ 5000 / \mathrm{ha}$ ) resulted from \\ optimizing 'Sharpblue' cross-pollination.
}

Blueberry production in the southeastern United States is based primarily on rabbiteye (Vaccinium ashei) blueberries. However, blueberry breeders also are developing highbush-type (V. corymbosum) cultivars adapted to the southern environment by incorporating genes from native species, notably V. darrowi and V. ashei. The initial highbush-type cultivars released, 'Flordablue', 'Sharpblue', and 'Avonblue' (Sharpe and Sherman, 1976a, 1976b; Sherman and Sharpe, 1977), have fruit development periods up to 30 days shorter than those for rabbiteye blueberries (Lyrene and Sherman, 1985). Thus, southern highbush blueberries can be marketed earlier than previously possible, resulting in premium market values (Lyrene and Sherman, 1984).

Although northern highbush blueberries are self-fertile, intervarietal vs. intravarietal pollination can affect fruit development. Cross-pollination has been cited to either improve or have no effect on fruit set and fruit size (Bailey, 1938; Merrill and Johnston, 1940; Morrow, 1943; White and Clark, 1939). Although Merrill and Johnston (1940) reported otherwise, Morrow (1943) and Brewer and Dobson (1969) found that cross-pollination also resulted in earlier fruit ripening and more developed seeds. Thus, blueberry production for early markets may be particularly influenced by pollen source, possibly by affecting seed development.

Little is known about pollination and fruit development in southern highbush blueberries. Their complex pedigrees reflect varying percentages of relatively self-fertile V. corymbosum germplasm with lesser amounts of relatively self-infertile Vaccinium species. For example, the primary southern highbush cultivar in current production, 'Sharpblue', has a pedigree of

Received for publication 7 Nov. 1990. Approved for publication by the Director of the Louisiana Agricultural Experiment Station as manuscript no. 90-28-4400. We acknowledge Joshua Tao for his assistance in analysis of seed counts, Dan Winfrey and Steve Buco for their assistance in data analyses, Jim Parrie for his suggestions and discussion, and Suzanne Lang for her assistance in fruit size measurements. The cost of publishing this paper was defrayed in part by the payment of page charges. Under postal regulations, this paper therefore must be hereby marked advertisement solely to indicate this fact.
$56 \% \mathrm{~V}$. corymbosum, $31 \% \mathrm{~V}$. darrowi, and $13 \% \mathrm{~V}$. ashei, and cross-pollination with 'Flordablue' was originally recommended (Sharpe and Sherman, 1976b). However, within 10 years of its release to growers, solid-block 'Sharpblue' plantings were being recommended due to its apparent self-fertility and the difficulty of growing 'Flordablue' (Krewer and Myers, 1986; Lyrene, 1986).

We began examining honey-bee-mediated pollination of 'Sharpblue' with itself or with the pollinizers 'Flordablue' (Lang et al., 1988) or a new, more vigorous cultivar, 'Gulfcoast'. The objectives of this study were to: 1) investigate the effects of 'Sharpblue' self- and cross-pollination at optimum pollinator levels on fruit and seed development, and 2) estimate the potential economic impact of any pollination treatment differences on crop value in the early blueberry market.

\section{Materials and Methods}

Plants and pollination treatments. In 1989, 3-year-old 'Sharpblue' and 'Gulfcoast' plants were grown in 9.8-liter pots of a 1 sand : 1 bark : 2 peat medium at the Louisiana State Univ. Horticulture Farm, Baton Rouge. Six $3 \times 3 \times 2.5-\mathrm{m}$ nylon mesh insect cages provided three single-cage replications for each pollination treatment. The photosynthetically active radiation (PAR) level measured (LI-COR Model 6200; LI-COR, Lincoln, Neb.) in each cage was $65 \%$ of full sun exposure. Each cage was supplied with a small honey bee colony that contained five frames of adult bees. In the caged environment, only a few bees foraged at any time; consequently, pollinator activity was not substantially different from a well-pollinated orchard. Each replication of the self-pollinated group consisted of eight 'Sharpblue' plants, and each cross-pollinated replication consisted of four 'Sharpblue' and six 'Gulfcoast' plants. The experiment was repeated in 1990 with similar conditions and 4year-old plants. The 1990 test yielded information on the relationship of seed count to fruit size and harvest date,

Evaluation of bloom. Plants held from late January in storage rooms at $4.5 \mathrm{C}$ were moved to the pollination cages on $1 \mathrm{Apr}$. (after the last likely frost date). All open flowers were counted 
on $4,7,11$, and 14 Apr. Under natural conditions, field-grown plants usually bloom around 1 Mar. The average number of 'Sharpblue' flowers per plant was 94. The estimated date of $50 \%$ bloom in each cage varied from 5 to 8 Apr. For the crosspollinated group, the average ratio of 'Gulf coast' to 'Sharpblue' open flowers ranged from 2.1 to 4.5 from beginning to end of 'Sharpblue' anthesis.

Fruit development. After anthesis and pollination, plants were removed from the cages and placed in a lath house under shade cloth (PAR level of $35 \%$ full sun). Plants were watered at least every 3 days and fertilized every 2 weeks with a $30 N-10 P-10 K$ (plus $\mathrm{S}+$ chelated $\mathrm{Fe}, \mathrm{Cu}$, and $\mathrm{Zn}$ ) water-soluble fertilizer.

In 1989, fruit ripening began on 18 May and continued through 5 June. Fruit set values were calculated on a per plant basis as (total fruits harvested)/(total flowers counted). During ripening, fruits were harvested and weighed every 3 days, and diameters were measured with a caliper. Fruits from each plant, at each harvest, were grouped according to size classes (small, 0.25$0.74 \mathrm{~g}$; moderate, $0.75-1.24 \mathrm{~g}$; large, $1.25-1.75 \mathrm{~g}$ ) to reflect a separation of premium market fruit $\operatorname{sizes}(\geq 0.75 \mathrm{~g})$. Fruits were stored at $-20 \mathrm{C}$ until the number of seeds per fruit was determined for samples of each size class. Five fruits per sample replication were macerated in $20 \mathrm{ml}$ of boiling water for 1 rein, and the flesh was rinsed from the seeds. Only seeds $\geq 1 \mathrm{~mm}$ long were recorded as fully developed.

In 1990, fruits were harvested every 2 days. To investigate the influence of seed count on harvest date, cross-pollinated fruits were grouped into three 12-day harvest intervals. Eight five-berry samples were drawn from two size classes, small (0.60-0.70 g) and large (1.30-1.50 g), at each interval, and seed count was determined as described above.

Means and standard deviations were computed from individual plant fruit set percentages, individual fruit weights, and fiveberry samples for seed counts. Differences between pollination treatments for fruit set, fruit weight, and seed numbers were evaluated with $\boldsymbol{t}$ tests. Pearson correlation coefficients (Steel and Torrie, 1980) were used to determine the degree of relationship between fruit weight and seed number. Two-way contingency tables (chi-square comparisons) were constructed to test the effect of pollination treatment on yields of selected harvest date/ fruit size combinations.

An economic analysis of crop value was made based on yield estimates of 1000 flats/ha (5.0 kg/flat) and 1988 fresh blueberry shipping prices (dollars/flat) as follows: 23 May, \$28; 29 May, \$18; 4 June, \$13 (Federal-State Market News Wire, 1988). These dates are several weeks later than 'Sharpblue' normally would be harvested in the coastal plains of the Gulf states because the experimental plants were stored in cold rooms until 1 Apr. As such, the shipping prices are more conservative than would normally be expected.

\section{Results and Discussion}

Fruit set. Fruit set did not differ significantly between selfand cross-pollinated plants (Table 1). Similarly, minor differences in cross- and self-pollinated fruit set also have been reported for southern highbush breeding lines (Gupton, 1984) and for highbush plants (Merrill and Johnston, 1940; White and Clark, 1939). Our results contrast with those of El-Agamy et al. (1981) and Lyrene (1989), who reported that cross-pollination increased 'Sharpblue' fruit set percentages by $5 \%$ to $22 \%$ and $37 \%$ to $54 \%$, respectively. Furthermore, the low (37\%) fruit set percentage Lyrene obtained for self-pollination contrasts with the $66 \%$ and $77 \%$ fruit set from our and El-Agamy et al.'s
'Sharpblue' self-pollinations, respectively. The differences in fruit set percentages between treatments in these studies maybe due to several factors. Pollination techniques differed: El-Agamy et al. and Lyrene used a single application of pollen by thumbnail compared to the probable repeated pollen transfers by honey bees in the present study. Sample sizes also varied greatly, with the data of El-Agamy et al. based on 133, that of Lyrene on 281, and of the current study on 2328 flowers.

Fruit weight. Cross-pollination increased fruit weight by $13.6 \%$ compared to self-pollination (Table 1). A similar influence of cross-pollination on 'Sharpblue' fruit weight was reported by Lyrene (1989), whose self-pollinated fruit were similar in size $(0.85 \mathrm{~g})$ to those reported here $(0.88 \mathrm{~g})$. However, Lyrene's cross-pollinated fruits were much larger than those in this study. This may be due to mixing of cross- and self-pollen during cross-pollination by bees, since Lyrene reported that a 1:3 mix of cross- and self-pollen resulted in intermediate influences on fruit (and seed) development. With honey-bee-mediated crosspollination, the different ratios of 'Gulfcoast' to 'Sharpblue' flowers (from 2.1 to 4.5 ) had no apparent influence on fruit development or seed count (data not shown). Mean fruit weight in both pollination treatments declined as harvest progressed (data not shown).

Seed number per fruit. Honey-bee-mediated cross-pollination increased the mean number of fully developed seeds per fruit by $27.5 \%$ compared to self-pollination (Table 1 ), suggesting the presence of a weak self-infertility mechanism (in contrast to the strong self-infertility exhibited by rabbiteye blueberries). A similar influence of cross-pollination on seed count in southern highbush blueberries has been reported (El-Agamy et al., 1981; Gupton, 1984; Lyrene, 1989). Fewer than four seeds per selfpollinated 'Sharpblue' fruit were fully developed when a single application of pollen by thumbnail was used (El-Agamy et al., 1981; Lyrene, 1989), whereas 13 developed seeds per fruit were obtained from bee pollination (Table 1). This result may be further evidence that repeated pollen transfers by honey bees are more effective than a single application of pollen.

Correlations between blueberry fruit size and seed count vary with species, cultivars, time of harvest, and other factors (Brewer and Dobson, 1969; Darrow, 1958; Lyrene, 1989; Moore et al., 1972). In 'Sharpblue', fruit size was highly related with seed count in cross-pollinated fruits, but the relationship was weaker in self-pollinated fruits (Table 1). These trends could indicate that seeds of different genetic derivation, although equally developed, differ in their influence on fruit growth. Furthermore, above a minimum seed count threshold, the influence of seed count on fruit size may be diminished, as Brewer and Dobson (1969) found in northern highbush. For example, self-pollinated 'Sharpblue' fruits in this and Lyrene's (1989) experiment were similar in size but differed by $4 \mathrm{x}$ in seed count.

As harvest progressed, mean fruit size and the mean number of fully developed seeds per fruit declined (data not shown), as also has been reported for northern highbush and rabbiteye blueberries (Darrow, 1958; Moore et al., 1972). However, examination of sets of similar-sized, cross-pollinated 'Sharpblue' fruits during the 1990 harvest revealed that seed count declined through time without affecting fruit size (Table 2), indicating that parallel declines in fruit size and seed count are not necessarily related. For example, large fruits $(1.40 \mathrm{~g})$ harvested during the final 12 days of ripening had 11.0 seeds/fruit, substantially less than the number of seeds in small fruits $(0.65 \mathrm{~g})$ harvested during the first 24 days of ripening. The data of Darrow (1958) indicate a similar trend. The cause of this decline in seed count 
Table 1. Fruit characteristics and associated correlations for caged 'Sharpblue' blueberry plants selfpollinated or cross-pollinated with 'Gulfcoast' (1989). Data are presented as $\bar{X} \pm \mathbf{s}$ (n). Probability levels are for comparisons of results within columns.

\begin{tabular}{|c|c|c|c|c|}
\hline Pollination & $\begin{array}{c}\text { Fruit set } \\
(\%)\end{array}$ & $\begin{array}{l}\text { Fruit wt } \\
\text { (g) }\end{array}$ & Seed no./fruit & $\begin{array}{l}\text { Correlation of } \\
\text { fruit wt } \\
\text { and seed no. }\end{array}$ \\
\hline $\begin{array}{l}\text { Sharpblue } \\
\times \text { Sharpblue } \\
\text { Sharpblue }\end{array}$ & $66 \pm 21(24)$ & $0.88 \pm 0.28(825)$ & $13.1 \pm 6.3(133)$ & $r=0.562(133)$ \\
\hline $\begin{array}{l}\text { X Gulfcoast } \\
\text { Probability } t\end{array}$ & $\begin{array}{c}62 \pm 15(12) \\
0.749\end{array}$ & $\begin{aligned} 1.00 & \pm 0.34(495) \\
& <0.001\end{aligned}$ & $\begin{aligned} 16.7 & \pm 8.1(79) \\
& <0.001\end{aligned}$ & $\begin{aligned} r= & 0.779(79) \\
& 0.002^{\mathrm{y}}\end{aligned}$ \\
\hline
\end{tabular}

${ }^{2}$ On a per plant basis.

YProbability $Z^{*}$ (Steel and Torrie, 1980).

Table 2. Relationship of harvest date to seed count in cross-pollinated 'Sharpblue' fruits of similar size (1990). Forty fruit per size class were analyzed.

\begin{tabular}{lccc}
\hline \hline & \multicolumn{3}{c}{ Harvest interval } \\
\cline { 2 - 4 } $\begin{array}{l}\text { Fruit size } \\
\text { class }\end{array}$ & 4-14 May & 16-26 May & 28 May-7 June \\
\cline { 2 - 4 } & \multicolumn{3}{c}{ No. seeds/fruit } \\
\hline Small & 18.2 & 14.2 & 8.8 \\
Large & 31.4 & 24.4 & 11.0 \\
\hline
\end{tabular}

${ }^{\mathrm{z}}$ Small $=0.60-0.70 \mathrm{~g}$; large $=1.30-1.50 \mathrm{~g}$.

has yet to be explained. However, such results suggest that the primary advantage of increasing the number of seeds per fruit would be to hasten fruit development and ripening across all size classes, resulting in earlier production overall.

Fruit development period. In 1989, harvest began on 21 May and ceased on 5 June. The average fruit development period (period from $50 \%$ anthesis to $50 \%$ ripe) ranged from $\approx 49$ to 56 days across treatments. This is 13 to 29 days less than the pollination-to-ripening intervals reported by Lyrene (1989) and is probably due to higher outdoor temperatures in April and May compared with Lyrene's greenhouse temperatures in January through April. Consequently, the large (as much as 23 days) differences Lyrene reported between pollination treatments were probably magnified by the lower temperatures during his experiment. When temperatures are more optimal for fruit growth, the differences in fruit development periods will probably be smaller for cross- vs. self-pollination treatments.

Accelerated fruit maturation with cross-pollination has been noted for both northern (Meader and Darrow, 1947; Morrow, 1943) and southern (Gupton, 1984; Lyrene, 1989) highbush blueberries. No previous studies have accounted for weekly differences in fruit size. In this study, harvests were combined into 6-day intervals to represent early, mid-, and late harvests (Table 3 ). Cross-pollination resulted in significantly higher proportions of early-ripening fruit $\left(34.1 \%\right.$ vs. $14.2 \%$; $\left.\mathrm{x}^{2}<0.001\right)$ and lower proportions of late-ripening fruit $\left(9.5 \%\right.$ vs. $\left.30.9 \% ; \mathrm{x}^{2}<0.001\right)$, with the proportion of fruit ripening in mid-harvest being nearly identical. Most of the increase in early-ripening fruit was from an increase in the number of premium fruits weighting $>0.75$ g $\left(29.8 \%\right.$ vs. $\left.11.3 \% ; \mathrm{x}^{2}<0.001\right)$. Furthermore, although the total proportion of mid-harvest fruit did not differ between treatments, cross-pollination resulted in a $10 \%$ increase in the midharvest proportion of premium fruit and a $13 \%$ increase in the overall proportion of premium market fruit (79.9\% vs. 66.6\%; $\left.\mathrm{x}^{2}<0.001\right)$.

Early market considerations. Many northern blueberry grow-
Table 3. The influence of pollination treatment on fruit weight and percentage of total yield (based on fruit number) harvested at early, mid-, and late ripening for 'Sharpblue' blueberry self-pollinated or cross-pollinated with 'Gulfcoast' (1989).

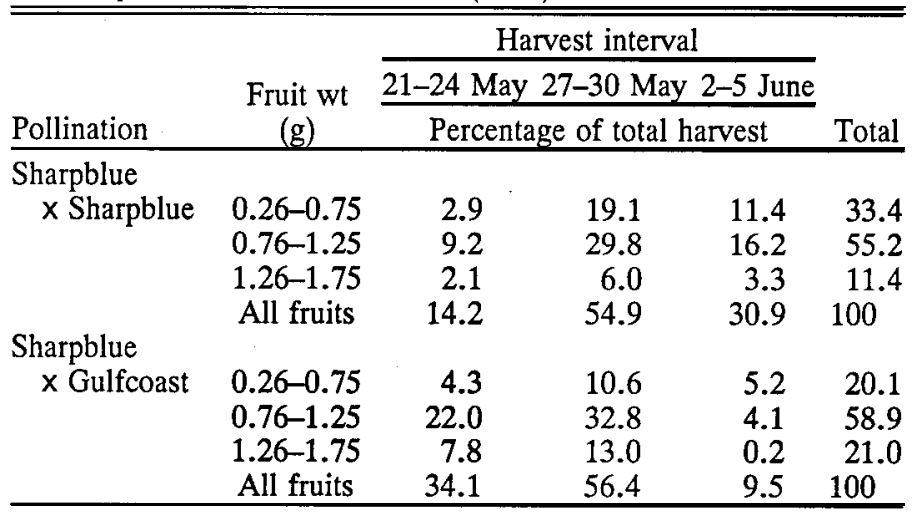

Table 4. Estimated difference in early market crop value when 'Sharpblue' blueberry is cross-pollinated or self-pollinated.

\begin{tabular}{lcc}
\hline & $\begin{array}{c}\text { Crop proportion and market } \\
\text { value at time of harvest }\end{array}$ & $\begin{array}{c}\text { Total crop } \\
\text { value } \\
(\$ / \mathrm{ha})^{\mathrm{z}}\end{array}$ \\
\hline $\begin{array}{c}\text { Pollination } \\
\text { Sharpblue } \\
\times \text { Sharpblue }\end{array}$ & $\begin{array}{c}11.3 \% \text { early }+35.8 \% \mathrm{mid}+19.5 \% \text { late } \\
\$ 3,164+\$ 6,444+\$ 2,535=\$ 12,143\end{array}$ \\
$\begin{array}{c}\text { Sharpblue } \\
\times \text { Gulfcoast }\end{array}$ & $\begin{array}{c}29.8 \% \text { early }+45.8 \% \mathrm{mid}+4.3 \% \text { late } \\
\$ 8,344\end{array}$ \\
\hline
\end{tabular}

${ }^{2}$ Analysis is based on premium market fruit $(\geq 0.75 \mathrm{~g})$ and yields of 1000 flats/ha at 1988 market prices (Federal-State Market News Wire, 1988).

ers continue to plant solid cultivar blocks (Eck, 1988), since production is for the mid-season fresh or processing markets and the benefits of cross-pollination are relatively minor. However, as Morrow (1943) noted, optimization of cross-pollination may be an important strategy for growers who produce fruit for the early fresh market. In the Gulf states, where production of 'Sharpblue' fruit has created a new early fresh market, the advantages of cross-pollination may substantially increase crop value. An economic analysis of treatment differences in 'Sharpblue' yield (Table 4) indicates that substantial increases in the proportion of earlier premium market $(0.75 \mathrm{~g}$ or larger $)$ fruit led to a $43 \%$ increase in crop value, or nearly $\$ 5000 / \mathrm{ha}$. In addition, cross-pollination resulted in a more concentrated harvest period, which may improve the economic efficiency of harvest. 
To summarize, maximizing 'Sharpblue' fruit production by optimizing cross-pollen transfer by honey bees significantly increased fruit size and earlier ripening. Such results project economically to a nearly $\$ 5000 /$ ha increase in crop value, although actual increases will vary by year, pollinator level, weather during pollination, and pollinizer planting schemes. No effect of pollen source on fruit set was found. The mechanism by which cross-pollination influences fruit development is not as clear as has often been indicated. Although non-self-pollen probably leads to better fertilization and/or less seed abortion, resulting in more seeds, seed count above some threshold level actually may play a more important role in promoting accelerated fruit development and earlier ripening, rather than heavier fruit.

\section{Literature Cited}

Bailey, J.S. 1938. The pollination of the cultivated blueberry. Proc. Amer. Soc. Hort. Sci. 35:71-72.

Brewer, J.W. and R.C. Dobson. 1969. Seed count and berry size in relation to pollinator level and harvest date for the highbush blueberry, Vaccinium corymbosum. J. Econ. Entomol. 62:1353-1356.

Darrow, G.M. 1958. Seed number in blueberry fruits. Proc. Amer. Soc. Hort. Sci. 72:212-215.

Eck, P. 1988. Blueberry science. Rutgers Univ. Press, New Brunswick, N.J.

El-Agamy, S. Z. A., W.B. Sherman, and P.M. Lyrene. 1981. Fruit set and seed number from self- and cross-pollinated highbush $(4 \mathrm{x})$ and rabbiteye (6x) blueberries. J. Amer. Soc. Hort. Sci. 106:443-445.

Federal-State Market News Wire. 1988. Shipping point trends. The Packer 98(24-25).

Gupton, C.L. 1984. Effect of pollen source on fruit characteristics of low-chilling highbush type blueberries. HortScience 19:531-532.

Krewer, G.W. and S. Myers. 1986. Commercial blueberry culture. Univ. of Georgia Coop. Ext. Serv. Circ. 713.
Lang, G.A., E.J. Parrie, and R.G. Danka. 1988. Influence of bee visitation and pollen source on fruit growth in southern highbush (Vaccinium corymbosum hybrid) blueberries. Abstr. 4th Intl. Symp. Vaccinium Culture. p. 42.

Lyrene, P.M. 1986. April 1986 Florida variety recommendations. Univ. of Florida Blueberry Grower Info. Sheet.

Lyrene, P.M. 1989. Pollen source influences fruiting of 'Sharpblue' blueberry. J. Amer. Soc. Hort. Sci. 114:995-999.

Lyrene, P.M. and W.B. Sherman. 1984. Breeding early-ripening blueberries for Florida. Proc. Fla. State Hort. Sci. 97:322-325.

Lyrene, P.M. and W.B. Sherman. 1985. Breeding blueberry cultivars for the central Florida peninsula. Proc. Fla. State Hort. Soc. 98:158162.

Meader, E.M. and G.M. Darrow. 1947. Highbush blueberry pollination experiments. Proc. Amer. Soc. Hort. Sci. 49:196-204.

Merrill, T.A. and S. Johnston. 1940. Further observations on the pollination of the highbush blueberry. Proc. Amer. Soc. Hort. Sci. 37:617-619.

Moore, J. N., B.D. Reynolds, and G.R. Brown. 1972. Effects of seed number, size, and development on fruit size of cultivated blueber: ries. HortScience 7:268-269.

Morrow, E.B. 1943. Some effects of cross-pollination versus selfpollination in the cultivated blueberry. Proc. Amer. Soc. Hort. Sci. 42:469-472.

Sharpe, R.H. and W.B. Sherman. 1976a. 'Flordablue' blueberry. HortScience 11:64-65.

Sharpe, R.H. and W.B. Sherman. 1976b. 'Sharpblue' blueberry. HortScience 11:65.

Sherman, W.B. and R.H. Sharpe. 1977. 'Avonblue' blueberry. HortScience 12:510.

Steel, R.G.D. and J.H. Torrie. 1980. Principles and procedures of statistics: A biometrical approach. McGraw-Hill, New York.

White, E. and J.H. Clark. 1939. Some results of self-pollination of the highbush blueberry at Whitesbog, N.J. Proc. Amer. Soc. Hort. Sci. 36:305-309. 